University of Maryland Francis King Carey School of Law

DigitalCommons@UM Carey Law

\title{
The Politics of Religious Establishment: Recognition of Muslim Marriages in South Africa
}

Peter G. Danchin

University of Maryland Francis King Carey School of Law, pdanchin@law.umaryland.edu

Follow this and additional works at: https://digitalcommons.law.umaryland.edu/fac_pubs

Part of the Human Rights Law Commons, and the Religion Law Commons

\section{Digital Commons Citation}

Danchin, Peter G., "The Politics of Religious Establishment: Recognition of Muslim Marriages in South Africa" (2013). Faculty Scholarship. 1315.

https://digitalcommons.law.umaryland.edu/fac_pubs/1315

This Book Chapter is brought to you for free and open access by the Francis King Carey School of Law Faculty at DigitalCommons@UM Carey Law. It has been accepted for inclusion in Faculty Scholarship by an authorized administrator of DigitalCommons@UM Carey Law. For more information, please contact smccarty@law.umaryland.edu. 


\title{
The Politics of Religious Establishment: Recognition of Muslim Marriages in South Africa
}

\section{Peter G. Danchin*}

\begin{abstract}
In making the (false) assumption of the reconciliation of the individual or community with the reason of the law, the [South African] Constitution arrives at the metaphor of Western metaphysics, logos reconciled with nomos .... In the metaphor of logonomocentrism, 'the claim of the unity of self and others in absolute reason of the law' is made. Logonomocentrism promises the truth of reason and the reason of law, which are both games of figurality and rhetoricity. If, however, there is asymmetry between the practices of religious persons and the reasons of the state (nomos), then the only way logonomocentrism deals with these relations is to 'other' and delegitimize these practices as aberrant and illegal. ${ }^{1}$
\end{abstract}

\section{Introduction}

Each of the chapters in this volume address different aspects of the same basic puzzle: what is the relationship between "religious establishment" and the closely related category of "religious freedom”? Conventional wisdom has it that the former is a contingent political issue addressed to the relationship between religion(s) and the State, while the latter is a universal moral issue addressed to the relationship between individual rights-bearers and the State. As understood in Anglo-American legal history, establishment or non-establishment are merely the particular forms of institutional relation that developed between England and the newly-separated English church in the mid-sixteenth century and between the newly-independent United States and a

\footnotetext{
* I wish to thank Waheeda Amien, Saba Mahmood, and Winnifred Fallers Sullivan for comments and suggestions as well as the participants in my South African Constitutional Law and Comparative Public Policy and Law Reform seminars for helpful discussions on the Muslim Marriages Bill.

1. Ebrahim Moosa, “Tensions in legal and religious values in the 1996 South African Constitution,” in Beyond Rights Talk and Culture Talk: Comparative Essays on the Politics of Rights and Culture, ed. Mahmood Mamdani (New York: St.
} Martin’s, 2000), 133. 
variety of religious arrangements, including state establishments, in the former colonies in the late eighteenth century. We can thus speak today of an "established church" or "official or dominant religion” as an enduring feature of modern national constitutions. But beyond the culturally and historically limited category of "establishment," we can also see today a tremendous variety of constitutional arrangements in the world prescribing different forms of relation between the State and religion(s). ${ }^{2}$ This includes a variety of forms of recognition of and formal relation to both majority and minority religions. ${ }^{3}$

The distinction between religion-state relations, on the one hand, and the right to religious freedom, on the other, allows us to see that there is no intrinsic or necessary correlation between the degree of "establishment" and the protection accorded to religious liberty. The United Kingdom, for example, has an established church, but at the same time accords robust legal protection to the individual right of religious freedom, while China has an avowedly secular public sphere but comparatively weak legal protection of the right. ${ }^{4}$

There are, however, at least two apparently intrinsic connections between the categories of establishment and right/freedom. The first is that these categories rest on an underlying assumption of secularism or "the secular." Whether and to what extent a religion is

2. On relations between religion and State in various national constitutions, see Peter G. Danchin, “Of Prophets and Proselytes: Freedom of Religion and the Conflict of Rights in International Law,” Harvard International Law Journal 49 (2008): 249, 297-307.

3. Spain and Italy, for example, have established "concordat” systems of recognition that provide different rights and privileges to religious communities which are characterized by the use of negotiated agreements between the State and federations of religious institutions often formed for the purpose of concluding and administrating the agreements. See Gloria M. Morán, “The Spanish System of Church and State,” Brigham Young University Law Review (1995): 544; Silvio Ferrari, “The Emerging Pattern of Church and State in Western Europe: The Italian Model,” Brigham Young University Law Review (1995): 428-29.

4. See W. Cole Durham, Jr., “Perspectives on Religious Liberty: A Comparative Framework,” in Religious Human Rights in Global Perspective: Legal Perspectives, eds Johan D. van der Vyver and John Witte, Jr. (Cambridge, MA: Kluwer Law International, 1996), 1-44. 
"established," and where and how to demarcate the lines between religion and politics, are ultimately questions for the state to decide. This is the defining feature, indeed essential paradox, of modern secularism. ${ }^{5}$ The second is that, while there may be no necessary correlation between establishment and the right to religious freedom, where the right is recognized by the State, its meaning and scope will be dynamically interrelated with the nature of the public sphere in a particular society. This last point is a source of great confusion today. Contemporary religious freedom discourse is shaped by two interrelated features: first, a conception of political authority not in terms of any formal relation between the state and religion(s), but in terms of secular neutrality, and second, a conception of the right in terms of freedom. The discourse is able to maintain its simultaneous, and ultimately paradoxical, claims to uniqueness (because neutral towards religion) and universality (because securing the right to freedom of religion) by defining each concept in terms of the other. The constantly oscillating dialectic between neutrality and freedom ensures that the nature of the public sphere is dynamically related to the scope of the right to religious freedom. ${ }^{6}$

What this conceptual structure means is that the political nature of the public sphere (i.e. the relation of actually existing religions and religious communities to the state) is in practice understood and configured in terms of a moral theory of individual rights (i.e. the relation of rights-bearers as legal subjects to the State). Conversely, the actual meaning accorded to the right to religious liberty in any particular case or controversy is in practice understood and configured in terms of the political nature of the public sphere. In this way, what was first a

\footnotetext{
5.Thus even the case of a constitutional provision such as Article 2 of the Egyptian Constitution which provides that "Islam is the religion of the State and shari'a is the main source of legislation” reflects the extent to which Egypt is embedded within the problem-space of modern secular power. See Hussein Agrama, Questioning Secularism: Islam, Sovereignty, and the Rule of Law in Modern Egypt (Chicago: University of Chicago Press, 2012). 6. See Peter G. Danchin, “Islam in the Secular Nomos of the European Court of Human Rights,” Michigan Journal of International Law 32 (2011): 663.
} 
political question becomes a moral question, and what was first a moral question becomes transformed into a political question. Both nomos (the public sphere) and logos (the right) are ineliminably contextual and interconnected. Any account of nomian neutrality will quickly devolve into hypostasis or reification of an historically specific political order and thus a particular definition of "religion and belief" and specific form of demarcation between "public and private” spheres. Any account of the right, when viewed historically, will reveal that rival intellectual traditions and normative dissonances and conflicts are internal to the right itself. The right, in other words, is simultaneously historically relative and normatively plural.

The thesis of this chapter is that the category of "religious establishment" has been gradually transformed in modern liberal secular discourse into the category of moral right-the right to religious liberty. What today is viewed as "established" is not actually existing, politically negotiated relations between the State and particular religious communities or institutions (e.g. "the church,”), but rather the legal category of "right.” Legal and religious obligations are re-described as rights of the subject in order to protect a normative conception of freedom. As legal subjects religious individuals and groups thus assert claims of right which the state must then decide through legislation or adjudication to recognize or restrict. This makes contestation over rights claims an increasingly political process and further increases the power of the state.

Two key issues remain: first, who is the proper subject of the right? Are only individual persons, or may religious groups, communities, and institutions also properly be regarded as entitled to claim the right to religious freedom? Second, what is the scope and meaning of the right? Does it encompass merely a right to non-interference in the so-called "private sphere" (and, if so, non-interference into what exactly?), or does it extend to various forms of public recognition and accommodation by the State (and, if so, to which claims and religious practices exactly and with what legal effect)? 
This chapter explores the normative dissonances and antinomies generated by the politics around religious establishment by examining post-apartheid law reform efforts in South Africa to recognize Muslim marriages. Since the late 1990s, the South African Law Reform Commission (SALRC) has initiated various projects to recognize the claims of and redress past discrimination against different religious communities, including tribal groups living under customary law and religious minorities with their own family and personal status laws. It is striking how the norms and assumptions underpinning this debate differ from engagements involving the claims of religious communities in Europe and North America today where broadly Protestant genealogies of the right to freedom of conscience have become naturalized. The value-pluralist nature of the post-apartheid constitutional order is transforming the politics between religious communities and opening new spaces for legal and social reform. We are thus seeing new and intense debates on questions of legal pluralism and the tensions between individual and group rights and identities. This dynamic provides important insights into the meaning and scope of religious freedom as a human right.

After a brief overview of the history of Muslim communities in South Africa and the reasons for the non-recognition of Muslim marriages, I describe the efforts undertaken by the SALRC to prepare a draft bill recognizing Muslim marriages as a matter of state law and the politics which has subsequently emerged around competing claims to and understandings of recognition of Muslim personal law (MPL), and I offer reflections on the reasons for and implications of these antinomies and divergences. The law reform efforts in South Africa have exposed critical ambivalences and normative resistance to the two great transformations which together define the modern politics of religious freedom: the first relating to the emergence of a "secular” public realm imagined to be independent of and in some new relation to "religion," now viewed as solely a matter for private life (the so-called public/private divide), and the second relating to the redefinition of religion itself as conscience or belief in an age of what we might 
term secular equality where the unstable convergence between conscience and autonomy has gradually reversed in the secular imaginary such that religious liberty is today viewed as autonomy.

\section{History of Muslim Communities in South Africa}

There have been Muslim communities in southern Africa for more than 300 years. ${ }^{7}$ The heterogeneity of these groups is a product of the history of settlement and colonialism in southern Africa from the mid-seventeenth to the mid-nineteenth century. Malay Muslims first came to the Cape as servants of the Dutch as early as 1658. Southeast Asian Muslims came as political prisoners, convicts, and slaves starting in 1667, and Indian Muslims began arriving in the mid1850s, first as indentured laborers imported to work on British sugar plantations in Natal and later voluntarily. ${ }^{8}$ Today, these communities are the largest religious minority in the country, comprising approximately 1.5 percent of the total population. ${ }^{9}$

State recognition of Islamic law and the organization of Muslim legal affairs generally was limited during this the first couple of centuries, and the extent to which Muslims in the Cape resorted to the official (secular) courts in matters of family law and succession is unclear. ${ }^{10}$ What is known is that, following the founding of the first mosque in the Cape around 1805, imams

7. Ebrahim Moosa, "Prospects for Muslim Law in South Africa: A History and Recent Developments,” Yearbook of Islamic and Middle Eastern Law 3 (1996): 130.

8. Through conversion these communities also include members of the indigenous African and European (white) communities. See Waheeda Amien, “Overcoming the Conflict between the Right to Freedom of Religion and Women’s Rights to Equality: A South African Case Study of Muslim Marriages,” Human Rights Quarterly 28 (2006): 731; Moosa, “Prospects for Muslim Law in South Africa,” 131.

9. Amien, 730 .

10. With the advent of the Dutch East India Company between 1652 and 1795, the Commander's Court accorded limited recognition of Islamic law to “non-slave Moslems with regard to matters of family law and succession,” but otherwise "all inhabitants, regardless of colour or status, came under Roman-Dutch law and such statutes as were of local operation.” Moosa, “Prospects for Muslim Law in South Africa,” 132. 
began to assert authority over family law matters and by the early nineteenth century "some form of community judicial structures were in place which dealt with religious matters of a legal nature.” 11

In the early twentieth century, the practice of Muslim personal law over matters of marriage, divorce, custody, and succession began to be administered judicially and socially by Ulama Councils (Muslim clergy). ${ }^{12}$ By 1935 the Jamiatul Ulama of Transvaal was established, the Muslim Judicial Council followed in 1945, and the Jamiatul Ulama of Natal was founded in 1955. Subsequently other ulama bodies emerged including the Majlis Ashura al-Islami in 1969, the Islamic Council of South Africa in 1975, the Sunni Jamiatul Ulama of South Africa in 1978, the Majlisul Ulama in 1976, and the Sunni Ulama Council in $1994 .{ }^{13}$ The state, however, consistently refused to recognize Muslim personal law, and thus Muslim marriages contracted according to Islamic law were not recognized, causing hardship and injustice to Muslim communities, especially women and children.

The doctrinal rational for non-recognition was stated as early as 1860 when the Cape Supreme Court refused to recognize an applicant as a legitimate child on the grounds that a Muslim marriage was "recognized concubinage" because potentially polygynous and thus contrary to public policy. ${ }^{14}$ This rationale remained in effect in South African law to the present day. As recently as 1983, the Appellate Division reaffirmed that an Islamic marriage was contra

11. While from the 1860 s to 1900 many cases involving disputes over mosque leadership and property disputes were taken to the Cape Supreme Court, "very few cases of divorce, custody and succession were reported to have reached the secular courts and there is every reason to believe that the community organs had successfully handled these.” Ibid., $133-134$.

12. The ulama provided religious services at mosques, instructed children and adults about religious doctrine, and applied “informal” personal law in the community. Ibid., 134.

13. Ibid.

14. Bronn v. Frits Bronn's Executors (1860) 3 Searle 313 at 318. In Seedat's Executors v. The Master 1917 AD 302 , the Court refused to recognize a Muslim widow as the surviving spouse for the purposes of the Natal Act which would have exempted her from estate duty. 
bona mores, i.e. "contrary to the accepted customs and usages which are regarded as morally binding upon all members of our society.”15

This close nexus between monogamy and "civilized" marriage can be traced to the complex entanglement of Christian norms and doctrine within South African law and culture. In the 1860 Bronn case, for example, the Cape Supreme Court stated that ... marriage is a condition Divine in its institution ... and it is only by the development of Christianity that the sacred and mysterious union has been clearly revealed to mankind, and has enjoined a strict observance of its requirements, and one of the first of these requirements is, amongst all Christian nations, that polygamy is unlawful, and that marriage is only good when contracted with a man who is not already married to another woman. ${ }^{16}$

This statement offers a classical legal conception of marriage as status-universal and fundamental to civilization and to law. ${ }^{17}$ As Janet Halley has observed, marriage as status is still today understood as "an institution, public not private, controlled by the will of the state, not that of the parties.” 18

The effect of this law was essentially threefold: first, South African Muslims as a community were discriminated against on the basis of their religion and treated as second-class citizens; second, Muslim personal law evolved and was applied by ulama bodies in isolation from both the obligations and rights accorded by state law; and third, unjust consequences resulted for Muslims who were denied legislative rights and benefits available to marriages recognized by civil law. A Muslim wife therefore could be unable to enforce her right to mahr

15. Ismail v. Ismail 1983 (1) SA 1006 (AD) at 1026. The Court stated that potential polygyny is tantamount to actual polygyny and any agreement (tacit or otherwise) between the parties cannot alter this.

16. Bronn (1860) 3 Searle 313 at 318. In Seedat's Executors v. The Master 1917 AD 302, at 307-308, the Appellate Division confirmed that polygamy is "reprobated by the majority of civilized peoples, on grounds of morality and religion.” See Amien, 733.

17. Janet Halley, “What is Family Law? A Genealogy: Part I,” Yale Journal of Law and the Humanities 23 (2011): 1-109. 18. Janet Halley, “Behind the Law of Marriage (I): From Status/Contract to the Marriage System,” Unbound 6 (2010): 4. 
(dower) due to strict interpretations of shari'a by the ulama in her community, while at the same time being unable to enforce a claim for maintenance under civil law due to non-recognition of her Muslim marriage.

While some of the more deleterious effects of these judgments have begun to be ameliorated by courts in the post-apartheid era, ${ }^{19}$ and while judges have begun to recognize certain aspects of Muslim personal law in the form of civil contracts, ${ }^{20}$ Muslim marriages remain unrecognized and thus potentially illegal as a matter of South African law. It was this unsatisfactory situation that led to the establishment of a Project Committee of the SALRC in 1999, which started an investigation into Islamic Marriages and Related Matters. ${ }^{21}$

\section{Legal Recognition of Muslim Marriages}

Section 15 and the Right to Freedom of Religion and Belief

Section 15 of the 1996 Bill of Rights introduced the following provision into South African constitutional law:

Everyone has the right to freedom of conscience, religion, thought, belief and opinion.

This section does not prevent legislation recognising

(i) marriages concluded under any tradition, or a system of religious, personal or family law; or

(ii) systems of personal and family law under any tradition, or adhered to by persons professing a particular religion. ${ }^{22}$

19. See Ryland v. Erdos, 1997 (1) BCLR 77 (C); Amod v. Multilateral Motor Vehicle Accidents Fund 1998 (4) SA 753 (CC).

20. Following Ryland and Amod, the proven terms of a civil contract such as "the husband's unilateral duty of support, his obligation to nafaqah (maintain) his wife during marriage and iddah, and payment of mahr, are legally enforceable.” Amien, 736.

21. South African Law Reform Commission, Project 59: Islamic Marriages and Related Matters, Report, July 2003, 1-2.

22. S. Afr. Const. 1996 ss. 15(1) \& (3)(a). Section 15(3)(b) also stipulates that “[r]ecognition in terms of paragraph [3](a) must be consistent with this section and the other provisions of the Constitution.” In addition to Section 15, Section 31 of the Constitution provides that "[p]ersons belonging to a cultural, religious or linguistic community may not be denied the 
The distinctive normative structure of Section 15 is instructive. The subject of the right is said to be "everyone" (presumably every "person") while the scope of the right is said to extend to "freedom of conscience, religion, thought, belief and opinion." It is not clear on its face whether this includes marriages concluded under systems of personal or religious law or the systems of personal or family law "adhered to by persons professing a particular religion" themselves. Section 15(3) simply states that "[t]his section does not prevent legislation recognising" such marriages or systems of personal or family law, with the proviso set out in Section 15(3)(b) that any such legislative recognition "must be consistent with this section [i.e. the right in Section 15(1)] and the other provisions of the Constitution.”

How should we interpret these provisions? Clearly Section 15(3) both anticipates and authorizes forms of legal relation between the State and South Africa's different religious communities, including groups living under customary law and religious minorities with their own family and personal status laws. Indeed, Section 15 expressly states that the right to religious freedom itself as embedded in the new Bill of Rights cannot be read to prevent the legal recognition of such religious practices and institutions (e.g. Muslim marriages) or systems of law (e.g. Muslim personal status law). In contrast to the Establishment Clause in the First Amendment to the U.S. Constitution providing that "Congress shall make no law respecting the establishment of religion,” Section 15 says that the national government may not prevent laws establishing forms of recognition of religion and religious doctrine and practice.

Given that the title of Section 15 is Freedom of Religion, Belief and Opinion, it is clear that the prohibition in Section 15(3) expresses an important aspect of this freedom. The category of religious establishment is employed here to define and protect a particular normative

\footnotetext{
right, with other members of that community (a) to enjoy their culture, practice their religion and use their language.” Section 235 further provides that the "right of South African people as a whole to self-determination ... does not preclude ... recognition of the notion of the right of self-determination of any community sharing a common cultural and language heritage, within a territorial entity in the Republic or in any other way, determined by national legislation.”
} 
conception of freedom while the category of right is identified as a potential limitation on that conception. Courts and legislatures are instructed by the Bill of Rights to read Sections 15(1) and 15(3) together, i.e. as entrenching a conception of the right that both allows space for and accommodates diverse forms of both collective religious practice and identity as well as non-state systems of personal or religious law. Any resulting recognition or accommodation, however, cannot be inconsistent with the right to religious freedom itself in Section 15(1) or any other fundamental constitutional rights such as the right to equality in Section 9.

The political questions of non-interference in or recognition by the State of religious norms and practices are ultimately held to be subject to the normative (moral) constraints of the right. At the same time, the subject and scope of the right are each ambiguous, allowing space for forms of (political) contestation and recognition of religious norms, identities, and practices. The question then becomes how these obvious antinomies and contradictions on issues of legal establishment, freedom and pluralism, and individual and group rights and identities are to be navigated and, if only provisionally, resolved.

\section{The Recognition of Muslim Marriages Bill}

In July 2003 the SALRC released its report on Islamic Marriages and Related Matters, including a draft of the Muslim Marriages Bill. The basic structure and purpose of the Bill was to make provision for the recognition of existing Muslim marriages (whether monogamous or polygynous) as well as existing civil marriages to a second wife. ${ }^{23}$ The Bill specifies the requirements of a valid Muslim marriage and provides for registration of such marriages. ${ }^{24}$ It further specifies that the proprietary consequences of Muslim marriages will be automatically out of community of property, unless the parties agree otherwise by registered antenuptial

23. Section 5 (Requirements for validity).

24. Section 6 (Registration). 
agreement. ${ }^{25}$ In relation to termination of Muslim marriages, the Bill specifies that this can be by faskh (dissolution by a court on the application of the wife), talaq (right of the husband to terminate), or khula (dissolution at the instance of the wife), but the consequences of such termination have to be confirmed by a court. ${ }^{26}$ The Bill also contains further provisions dealing with custody and maintenance. ${ }^{27}$ It is interesting to note that the Bill does not provide for independent shari'a courts, but rather seeks to implement Muslim Personal Law in the existing court system with the requirement that a Muslim judge or advocate and two Muslim assessors be appointed to assist the court. ${ }^{28}$ Court decisions are then subject to appeal to the Supreme Court of Appeal with the proviso that decisions are submitted to two accredited Muslim institutions for written comment on questions of law only. ${ }^{29}$

Waheeda Amien has described the two main benefits of the Bill as allowing Muslim parties to enjoy similar civil benefits as afforded to legal spouses while also allowing women to enjoy the positive benefits of a Muslim marriage. This includes the provisions which (1) oblige parties to provide for mahr; (2) recognize the husband's unilateral obligation to maintain his children and wife during the marriage and iddah; (3) oblige the husband in cases of divorce to provide a separate residence for the wife when she has custody of the children; (4) entitle the wife to be separately remunerated for breast-feeding purposes for two years from the birth of the child; (5) enable the court to make an equitable division of assets where a party has assisted in the

25. Section 8 (Proprietary consequences and contractual capacity of spouses). Section 8 contains further provisions (subsections (4)-(10)) dealing with the equitable regulation of the proprietary consequences of polygynous marriages. For further discussion, see Part IV.D.

26. Section 9 (Termination).

27. Section 11 (Custody of and access to minor children); section 12 (Maintenance). The Bill ensures legal recognition of spouses married according to Islamic law by further calling for amendments to the Deeds Registries Act 47 of 1937, the Intestate Succession Act 81 of 1987, and the Maintenance of Surviving Spouses Act 27 of 1990.

28. Section 15(1)(a) and (b).

29. Section 15(4). For further discussion, see Part IV.C. 
family business or contributed to the estate; (6) enable a surviving spouse to lodge a claim against her deceased husband's estate for unpaid mahr and any contribution recognized by shari'a that she makes to his estate; (7) provide a minimum marriageable age of 18 years applicable to both parties; (8) recognize different forms of divorce available to women such as faskh, khula, and talaq, rather than simply talaq as the exclusive domain of the husband; and (9) recognize polygyny, but only in a limited form regulated to protect the interests of women. ${ }^{30}$

The negative aspects of the Bill from Amien's perspective include (1) the traditional Muslim approach to matrimonial property in the form of an out of community of property regime (although with an opt-out provision); (2) the fact that husband and wife are equal in human dignity, status, and capacity, but are not equal in rights (e.g. the husband only is allowed to take multiple wives and the wife is under a unilateral obligation to observe iddah); (3) the exclusive right of men to unilaterally repudiate the marriage (talaq); and (4) the placing of interpretation and implementation of these provisions in the hands of Muslim judges and assessors required to have "specialized knowledge of Islamic law" which makes the Bill susceptible to conservative interpretations of shari'a. ${ }^{31}$

In order to see what is at stake in these competing positions, let us turn to consider the politics surrounding these issues which has evolved during the law reform process.

\section{The Politics of Religious Establishment}

As early as 1975, efforts were made to begin recognizing certain aspects of the legal consequences of Muslim marriages in South African law. The main supporters of these early initiatives were the established ulama groups. Others opposed these efforts as they suspected they "had more to do with the attempt to purchase legitimacy for the disgraced tricameral

30. Amien, 743-44.

31. Ibid., 745-46. 
parliament following the resistance that many Muslim groups offered the National Party government.”32 As Moosa acutely observes, Muslim responses to the overtures made by the apartheid state reverberated in "several registers of discourse" at the same time, and in them "one can discern the texture of colonial and racial discourses which run concurrently with the variety of Muslim discourses." These multiple discourses were "fractured and incomplete" and enfolded within themselves "conflicting and subterranean discourses," with the result that "discrimination, resistance, religion and culture to mention a few issues, appear as moving categories whose political saliences shift in relation to one another.” ${ }^{33}$ In the turbulent politics of the 1980s, the strongest resistance to SALC reform initiatives came from Muslim youth activists and students who "suspected that the state with its array of intelligence and security networks in collaboration with quietest and reactionary Muslim elements were planning to neutralize the Muslim community with MPL.”34

In response to the post-apartheid law reform proposals, it is possible to identify four distinct yet deeply entangled normative positions staked out by the various groups (both Muslim and non-Muslim) supporting or opposing legal recognition of Muslim marriages. Let us consider each of these before turning to address the justifications and practical implications of each position.

\section{Four Perspectives and Reactions to the Bill}

Support for the Bill has come from two camps. First are human rights organizations and activists, including "secular" Muslim groups and politically liberal organizations as well as the

32. Moosa, "Prospects for Muslim Law in South Africa," 135-137.

33. Ibid., 136.

34. Ibid., 138. Consistent with policies regularly employed by the apartheid state, “[s]tate propagandists continuously distinguished between the 'good' subject and the 'bad' subject, counterposing them as 'peace-loving' versus 'radical' Muslims and Christian clergy and their followers.” 
SALRC which together support legal recognition as a means to remedy the history of injustice, prejudice, and discrimination in South Africa against Muslims. The Bill, it is argued, would bring South African law more in line with the values of freedom, equality, and pluralism enshrined in the new constitutional order and, despite inevitable and legitimate challenges on grounds of gender equality, will provide more protection for the rights of Muslim women than the status quo. In line with contemporary constitutional jurisprudence, this is a position grounded in notions, not of formal, but substantive equality.

The second camp are so-called "progressive” ulama and other Muslim civil society organizations, which recognize the social and political reality of Muslims as a religious minority in the new constitutional order, and see the Bill as a reasonable way to protect Islamic values and norms by incorporating Muslim personal law into South African law and seeking a balance and compromise with constitutional rights and imperatives. Despite opening Muslim personal law to state regulation, these groups argue that legal recognition will paradoxically provide Muslims input and a degree of influence over any state interference while simultaneously elevating Muslim personal law to a more equal status in the public sphere, thus remedying both symbolically and substantively the historical mistreatment of Muslims as second-class citizens.

Opposition to the Bill has also fallen into two broad camps. First are the more stridently secularist and comprehensively "liberal" groups, who oppose the Bill as excessively entangling the State with questions of Islamic law and unconstitutionally enacting regressive and discriminatory Islamic norms and practices into state law. Prominent women's rights activists have thus argued that the drafting process was "manipulated to appease the Muslim clergy" and that, if enacted, the Constitutional Court will need to decide "how to deal with the conflict between the right to freedom of religion and women's rights to equality." 35 Excessive entanglement, however, also includes concerns about religious freedom. For constitutional 
lawyers such Ziyad Motala, the draft Bill is thus "an unwise, improvident and questionable constitutional exercise.” ${ }^{36}$ Religion is a matter of voluntary choice, and the State should not transgress into the sphere of private belief or interfere with the autonomy of religious institutions. Conversely, the State should not endorse or become entangled in matters of religion, and the right to religious liberty should be understood as protecting inner conscience, belief, or opinion, not religious conduct falling into the sphere of legitimate legal jurisdiction. This kind of negotiated and contingent modus vivendi is dangerous for both the State and religion — which should be kept separate.

Paradoxically many of these concerns mirror those voiced by the second major opposition camp comprised of the more traditional ulama bodies and "conservative” Islamic organizations. These groups have opposed state regulation of Muslim personal law by a non-Islamic state and have argued for maintenance of the status quo where ulama institutions and officials both interpret and administer Muslim personal law within their communities. Indeed, the notion of legal recognition has been argued to be against shari'a as it risks state interference with basic tenets of Islamic law precisely on the basis of the new constitutional values of freedom, equality, and pluralism. For this reason some of these groups have advocated for full exemption of "Muslim family law legislation from the human rights provisions of the new constitution, arguing that these values conflicted with their version of Islamic law.”37

It is striking to observe how the main fault-lines of disagreement correspond to the two issues discussed at the beginning of this chapter, religious establishment in the public sphere (nomos) and the right to religious freedom (logos), and the paradoxical ways in which each category is contested and defined in terms of the other. Thus both camps opposing the Bill can be seen to be resisting the interrelation of this dialectic. The traditional ulama bodies seek robust

\footnotetext{
${ }^{36}$ Ziyad Motala, “The Draft Bill on the Recognition of Muslim Marriages: an unwise, improvident and questionable constitutional exercise,” Comparative and International Law Journal of South Africa XXXVII (2004): 328. 
recognition from the State as collective legal subjects with a broad right to non-interference (liberty). Their co-oppositionists oppose the Bill paradoxically for exactly the opposite reason: they seek to deny any broad notion of a group right to religious freedom and argue instead for a more substantively "secular" account of the public sphere premised on a narrower conception of individual right. This still entangles the State in concerns of "religion," but now only in relation to a significantly narrower conception of individual "conscience," "belief," and (private) “practice.” This normative conception both requires a redefinition of what constitutes religion and a proper religious subjectivity ${ }^{38}$ and at the same time empowers the State to intervene more aggressively for regulatory purposes in any communal, traditional, customary, or religious spheres of life currently under non-state forms of authority. Indeed, the very purpose and rationality of such regulation is to "liberate" individuals from oppression or backwardness of traditional forms of authority. On this view it would be preferable for Muslim personal law ultimately to wither way as an anachronism or greatly be reduced in its scope and social power by being replaced with a system of uniform civil law. ${ }^{39}$

We see a mirror opposite in the camps supporting the Bill. Like the traditional ulama bodies, political, liberal, and secular Muslim groups argue for a broad collective right to religious freedom, but not for the purposes of non-interference. What they seek is public recognition. The public sphere should be open to and engage with different collective religious identities and norms, but should be subject to the overriding secular discipline and normative constraints of the

\footnotetext{
38. Saba Mahmood notes that "contrary to the ideological self-understanding of secularism (as the doctrinal separation of religion and state), secularism has historically entailed the regulation and reformation of religious beliefs, doctrines, and practices to yield a particular normative conception of religion (that is largely Protestant Christian in its contours) and that “[h]istorically speaking, the secular state has not simply cordoned off religion from its regulatory ambitions but sought to remake it through the agency of the law.” “Religious Reason and Secular Affect: An Incommensurable Divide?” in Is Critique Secular: Blasphemy, Injury, and Free Speech (Berkeley, CA: Townsend Center for the Humanities, 2009), 85-86.
} 39. See Susan Moller Okin in Is Multiculturalism Bad for Women, eds Joshua Cohen, Matthew Howard, and Martha C. Nussbaum (Princeton, NJ: Princeton University Press, 1999), 22-23. 
Constitution itself. From an opposite vantage point, moderate ulama and "progressive” Muslim civil society groups argue similarly for public recognition, engagement, and access to justice, but subject to the normative demand of reasonable accommodation by the State of Islamic norms and practices.

What makes consideration of these issues so difficult and divisive is that these four positions are often run seamlessly together, confused by proponents and opponents alike, or are considered in isolation from each other. We can see, for example, how supporters of the recognition of Muslim personal law, especially those within Muslim communities, are concerned not only with the right to freedom of religion or belief, but also with issues of women's rights and gender equality (especially as these rights have historically been violated by state action.) Polemical portrayals of the patriarchal nature of Islam and of aggressive Islamist politics in the public sphere and the framing by Muslim leaders of their claims in the name of religion and religious freedom only combine to obscure this more subtle dialectic. Conversely we can see how the arguments of secular opponents of recognition implicate not only on issues of gender equality, but also the scope and meaning of the right to religious freedom. Critical judgments made by law reformers and rights activists regarding the justice of Islamic norms on the grounds of divergence from assumptions internal to liberal theory obscure the degree to which these claims rest on contingent and contested accounts of the right to freedom of religion or belief itself.

In this type of situation then, where a minority asserts claims of right against the majority while at the same time asserting the legitimacy of certain internal communal restrictions, we face a far more complex and multifaceted dialectic than is often supposed. Such situations compel us to take seriously the plurality of whole ways of life complete with their associated conflicting moralities and often exclusionary allegiances. This, in turn, requires us to confront conceptions of the good that resist legal privatization and relegation to the private sphere of voluntary 
association which is their fate under the neutrality of the liberal state. The type of modus vivendi pluralism we see emerging in South African seeks a priori not to suppress or deny these types of demands, but rather to create a diversity of jurisdictions or normative domains for the various contending communities to reach (provisional) settlements.

This is a distinctly "mixed" conception of political order, with all the conflicts of jurisdiction that such plural inheritances give rise to in the laws of marriage and the family, and in this way it complicates the neat public/private divide imagined in liberal theory. It further illustrates how the right to freedom of religion is not a singular notion, but rather a complicated bundle of entitlements, each made up of a diversity of claims, and thus protects a range of human interests that are often at odds. When conflicts arise, as they inevitably do, these can reasonably be settled in different ways, making a general or universal theory impossible.

\section{Legislative Recognition versus Judicial Adjudication}

There are three further important implications that follow from this conception of the relationship between religious establishment and religious freedom. The first is the important practical difference between recognition via legislative reform as opposed to via judicial process and adjudication. While both involve a conception of religious establishment in terms of religious freedom, the mode and practical terms of engagement are quite different. The reform process seeking legislation recognizing Muslim marriages is clearly not a concordat or formal legal agreement between the State and a religious community. ${ }^{40}$ It does, however, contain some similarities. Since 1996 the SALRC has engaged in a far-reaching and ongoing process of outreach, requests for submissions, hearings, and negotiation on reform proposals with South Africa's Muslim communities and ulama organizations. This has required the State to engage directly with affected communities and thus with the conflicts and divergent politics that any

40. See note 3 . 
such engagement entails. For all its contradictions and perceived weaknesses, the 2003 Bill is a reflection of this substantive political engagement.

It is instructive to compare this with the religious freedom jurisprudence of the Constitutional Court during the same time period. The Court has decided three major cases under Article 15 since $1996 .{ }^{41}$ Despite its rhetoric of religious pluralism, associational autonomy, and reasonable accommodation, and despite the explicit collective rights provisions in the Bill of Rights, the Court has decided each of these leading Section 15 cases in favor of restricting claims to religious freedom and against challenges to unfair discrimination on the basis of religion. This supports the contention that the moralizing politics of religious freedom diverge in important respects from the messy politics of religious establishment as represented by the SALRC project to recognize Muslim marriages.

The adjudication of rights claims assumes the form of a techne or technology of liberal governance which, paradoxically, serves to increase the power of the State by restricting or dismissing the claims to religious freedom and collective identity of actually existing religious communities. This obscures the extent to which South African law and the public sphere remain entangled both directly and indirectly with Christian norms, symbols, and practices, ${ }^{42}$ and illustrates how a majority of the Court has been willing to interpret the right to religious freedom and the prohibition on unfair religious discrimination to give priority to the values of the majority religious culture. ${ }^{43}$

\footnotetext{
41. S. v. Lawrence; S. v. Negal; S. v. Solberg, 1997 (4) SA 1176 (CC); Christian Education South Africa v. Minister of Education, 2000 (4) SA 757; and Prince v. President, Cape Law Society, 2002 (2) SA 794.

42. See Jerry S. Ismail, “South Africa’s Sunday Law: Finding a Compromise,” Indiana International and Comparative Law Review12 (2001): 563-86.

43. As discussed in Part II, the secular and religious spheres were intimately linked during the apartheid era, and issues such as Sunday closing laws reflect this continuing entanglement. Christof Heyns and Danie Brand, “The Constitutional Protection of Religious Human Rights in Southern Africa,” Emory International Law Review 14 (2000): 760-61.
} 
Shari'a as Muslim personal law in the Spaces of Modern Secular Power

A second striking feature of the 2003 Bill is Section 15, which provides for disputes relating to "the interpretation or application of any provision” to be referred to a court for adjudication, but on the proviso that a "Muslim judge from that court" or, in the alternative, a senior "Muslim advocate or attorney,” is appointed to hear the dispute at first instance. ${ }^{44}$ The court is then to be “assisted by two Muslim assessors who shall have specialized knowledge of Islamic law.”45 Any decision can be appealed to the Supreme Court of Appeal, but the decision must also be submitted to two accredited Muslim institutions "for written comment on questions of law only," which must be lodged within 60 days with the Registrar of the appeal court. ${ }^{46}$

Here again we can see the various ways in which this mixed institutional arrangement tracks the four dynamics discussed above. The courts may not apply a uniform civil law of marriage to all spheres of social life, nor may they apply (even if it were possible) shari'a to the exclusion of existing state law. The courts may further not deny recognition of Muslim personal law as in the past, leaving the social practice and regulation of Muslim marriages to ulama bodies. Rather the Bill requires the court to apply a statute that both recognizes and regulates aspects of Muslim personal law. This hybrid normativity is reflected in both the procedural and substantive structure of the court itself, which requires Muslim judges to interpret and apply both Islamic law (as incorporated in the statute) and constitutional rights and values in relation to Islamic norms and practices.

This dialogic and mediating conception of both law and the role of legal officials is also apparent in the appeal structure. Final authority is vested in the Supreme Court of Appeal, which has the power to overrule legal interpretations by Muslim judges assisted by two specialist assessors (i.e. to overrule judgments concerning the proper relationship between different sources

44. Section 15(1)(a).

45. Section 15(1)(b).

46. Section 15(3) and (4). 
and jurisprudential schools of both state and Islamic law) ${ }^{47}$ But before doing so, the Court must consider and expressly overrule the opinions of two ulama bodies. What Robert Cover once termed the "jurispathic power" of the state-the state's domination of autonomous paideic communities under a unitary law-must in this way justify any coercive suppression of the “fecundity of the jurisgenerative principle.” 48

This dialogic hybrid conception of adjudication sits uneasily between shari'a courts presided over by qadis engaged in ijtihad, on the one hand, and secular courts enforcing Muslim personal law norms as encoded into statutes, on the other. The question is how Islamic norms are to be incorporated into state law and how legal officials are to interpret those norms once codified. Certain Muslim legal scholars, for example, have criticized the definition of mahr in the Bill, which they argue departs from classical Islamic law. ${ }^{49}$ Similarly scholars have

47. It is instructive to compare South Africa and India on this issue. Parties to a Muslim marriage in South Africa are required to opt-in to the provisions of the Act (section 2(1)), and the Supreme Court of Appeal retains final adjudicatory authority regarding disputes (section 15(4)). In India, by contrast, the parties to a Muslim marriage must expressly opt-out of relevant Muslim personal law provisions if they wish a dispute to be adjudicated according to uniform civil law (see the Muslim Women (Protection of Rights on Divorce Act, 1986, sect. 5 and the Shariat Act of 1937, which provides that in all matters of family, including divorce and maintenance, courts will decide such questions in the light of the Shariat).

Following Shah Bano, the Supreme Court of India has been cautious on the question of overriding Muslim personal law provisions in favor of uniform civil or criminal laws.

48. Robert Cover, “Nomos and Narrative,” in Narrative Violence and the Law: The Essays of Robert Cover, Martha Minow, Michael Ryan, and Austin Sarat, eds. (Ann Arbor: University of Michigan Press, 1995), 57.

49. Section 1 of the Bill states that mahr is payable by the husband to the wife "in order to establish a family and lay the foundations for affection and companionship.” The Quranic definition, however, is as follows: “And give unto the women, (on marriage) their dower as a free gift; but if they of their own accord remit unto you a part thereof, then you are welcome to absorb it (unto your wealth).” Quran Chapter 4:4. As Agherdien observes, the Section 1 definition appears to imply "some sort of obligation on the wife to use her mahr/dower to benefit the family unit,” whereas under the Quranic definition "the wife has full control over her dower, with absolutely no strings attached" and is thus on the part of the husband "an admission of the independence of the wife.” Wesahl Agherdien, “Muslim Personal Law in South Africa,” South African Journal on Human Rights Conference, July 5-7, 2004, 18-19. 
questioned how Muslim judges and assessors are to choose between and apply different schools of Islamic jurisprudence in cases involving different claimants. ${ }^{50}$ Finally, there is the question of what "Islamic law" is exactly and how it is to be identified. ${ }^{51}$

While these are complex and contested questions, they are the kinds of normative dilemmas that a value pluralist theory of law both anticipates and celebrates. The logic of Section 15 is that the very presence of Muslim judges and assessors on state courts combined with the advisory role of ulama bodies has the potential to create dynamic opportunities for interpretation and development of the law in dialogue between the courts and South Africa's Muslim communities. This is hoped to avoid the otherwise ossifying effects of shari'a being codified into state law in the form of Muslim personal law. ${ }^{52}$ Regardless of these jurisprudential debates, this clearly represents a different normative conception of freedom, religion, community, and the individual to that imagined in classical liberal theory with its rigid insistence on state neutrality mediated by a scheme of individual rights.

Finally, the Bill reflects the extent to which shari'a today has taken on distinctly liberal characteristics and sensibilities under the secular framework of the South African constitution. As Saba Mahmood has suggested in the Egyptian context, shari'a has been fundamentally transformed and now inhabits the spaces of personal status or religion-based family law under the

50. As observed again by Agherdien (ibid. 21):“The body of Muslim law used in South Africa dates back to the nineteenth century Muslim law schools of the Middle East, namely the Hanafi and Shafi schools of jurisprudence. Thus, the present Bill seems to be a hopscotch combination of those schools .... [and] remains silent on how it will deal with a conflict of schools.” 51. The 2010 version of the Bill includes a definition of Islamic law as “the law as derived from the Holy Qur'an, the Sunnah (prophetic model), the consensus of Muslim Jurists (Isma), and analogical deductions based on the primary sources (Qiyas).” For comments, see Waheeda Amien, “Politics of Religious Freedom in South Africa,” The Immanent Frame, 24 July 2012, available at: http://blogs.ssrc.org/tif/2012/07/24/politics-of-religious-freedom-in-south-africa/ (accessed October 21, 2012).

52. The irony here being the recurrent caricature of Islamic law as “a stagnant entity and, hence, impervious to change.” Ebrahim Moosa, “Colonialism and Islamic Law,” in Islam and Modernity: Key Issues and Debates, eds Muhammad Khalid Masud, Armando Salvatore, and Martin van Bruinessen (Edinburgh, UK: Edinburgh University Press, 2009), 165. 
regulatory discipline of the state, which grants religious groups certain juridical autonomy over family affairs.

As we have seen, this dynamic is reflected in the fourth position responding to the Bill as the traditional ulama bodies have resisted the proposed legislation on the grounds that Muslim personal law comprises the core of Islamic tradition and identity. Again Section 15 seeks to respond to these concerns by ensuring that both Muslim judges and ulama bodies are integrally involved and consulted in any judicial changes to Muslim personal law. Section 13 further requires compulsory mediation between the parties before an accredited Mediation Council prior to adjudication. For the ulama this provision was seen as an important medium through which to manage and resolve disputes regarding marriages and divorce outside of State courts and law.

The latest version of the Bill reflects the continuing anxiety and political tensions between the four camps over these issues. Reflecting the concerns of its secular opponents, the 2010 Bill now no longer contains Section 15 requiring a Muslim judge or the need for Muslim assessors, and the requirement of binding mediation has been replaced with a proposal for voluntary mediation. Reflecting the concerns of its ulama opponents, however, the Bill now contains an explicit definition of the sources of Islamic law which is likely to limit the discretion of judges in interpreting and changing Muslim personal law norms. ${ }^{53}$

\section{Family Law and Muslim Personal Law}

A final striking aspect of the politics surrounding the Bill has been the question of the relationship between "family law" and "Muslim personal law." Criticisms of the Bill by gender equality advocates have often been premised on the assumption that recognition of Muslim personal law is antithetical to the guarantee of gender equality in family law. For example we have seen how the Bill codifies the default position regarding the proprietary consequences of

53. For discussion, see footnote 51. 
marriage in Islamic law by providing that, unless an ante-nuptial contract is entered into by the spouses and registered, a "Muslim marriage to which this Act applies shall be deemed to be a marriage out of community of property, excluding the accrual system." 54 This differs from the civil law position where the default rule is "in community of property." 55 The Bill further specifies that in registering a Muslim marriage the marriage officer must record "the dower agreed to." ${ }^{56}$ The term "dower" or "mahr" is then defined as "the money, property or anything of value, including benefits which must be payable by the husband to the wife as an ex lege consequence of the marriage itself in order to establish a family and lay the foundations for affection and companionship." ${ }^{57}$ These provisions have attracted criticism for codifying discriminatory differences between men and women: the husband only is required to pay the mahr and to maintain his wife both during and after the marriage; upon the dissolution of marriage, the wife has property rights only out of community of property (without accrual), and her right to maintenance is only for the period of iddah (three months). Such differences are argued to violate the right to equality, and gender rights advocates have thus viewed this form of legal recognition of Muslim personal law a priori as a threat to women’s rights.

While space precludes detailed consideration of these questions, there are a number of reasons why such critiques rest on often problematic assumptions that serve to exacerbate rather

54. Section 8(1). Thus the spouses maintain their own estate, and any growth accrued during the marriage is not divided between them. This is subject to Section 9(7)(b), which allows the court to make an order for the equitable division of assets where a party has assisted in the operation of the family business or contributed to the maintenance or increase of the other's estate.

55. Marriage Act 25 of 1961.

56. Section 6(3)(c).

57. Section 1(vi). In relation to maintenance, the "husband is obliged to maintain his wife during the subsistence of a Muslim marriage according to his means and her reasonable needs." In the case of dissolution or divorce, "the husband is obliged to maintain the wife for the mandatory waiting period of 'Iddah' and, if she has custody of minor children, "to remunerate the wife, including providing a separate residence if the wife does not own a residence, for the period of such custody only.” Section 12(2)(c)(i) and (ii). 
than address the otherwise genuine concerns they raise. The first is what may be termed the "incomplete secularization of family law" thesis. As Mahmood has suggested in the context of postcolonial states in the Middle East, the "continuing persistence of religion-based family laws $\ldots$ is often seen as a sign of the incomplete secularization of these societies and the failure of the postcolonial state to draw a firewall separation between religion and the state." ${ }^{58}$ Viewed as an outdated and pre-modern remnant, such religion-based family laws "are understood to exhibit an ossified and recalcitrant quality that should have been remedied by the secularizing force of civil law." 59 But as many scholars have shown, this account fails to appreciate how "the telescoping of religious law into the domain of the family is not so much a violation of secular principles as it is the product of the simultaneous relegation of religion, family, and sexuality to the private sphere under the regime of modern governance.” ${ }^{60}$ The result of this privatization under the modern power of political secularism is that

[f]amily law as a distinct legal domain is a modern invention that did not exist in its present form in the premodern period. Classical sharia jurisprudence did not, for example, entail a separate domain called 'family law' .... [and] what is now associated with the core and essence of religion (Christian and Muslim alike), that is, personal status or family law, is an amalgam constructed from a variety of customary and religious jurisdictions that came to acquire an autonomous and distinct character in the modern period. ${ }^{61}$

Once this historical genealogy is recognized, the notion that complete secularization of religionbased systems of family law will lead to increased gender equality becomes inherently problematic. Indeed, as the family has become "a key site of intervention for projects of social reform undertaken by the state” in the modern period, this has in many cases served to increase

58. Mahmood, 57.

59. Ibid.

60. Ibid., 58.

61. Ibid. 
gender inequality, especially in relation to the institution of marriage. ${ }^{62}$

Viewing family law and the institution of marriage as sites of inequality and exceptionalism ${ }^{63}$ can help us to see the extent to which the existing system of family law in South Africa is deeply entangled with Protestant genealogies and understandings of the family. ${ }^{64}$ The extent to which marriage as an institution remains an established status that is implicated in the functions of both social order and personal freedom generating its own inherent inequalities will further be apparent. ${ }^{65}$ Following Janet Halley this would suggest that we should pay more careful attention to the marriage system as a whole-including its various "drop-off" and "formpluralism" elements—and the complex ways in which it paradoxically intertwines both status and contract. ${ }^{66}$ This would allow us critically to examine the multifaceted, exclusionary, and unequal effects of the South African marriage system which now includes civil, common law, customary, same-sex, domestic partnership, Muslim, and (currently under consideration) Hindu marriages.

\section{Conclusion}

The chapter has argued that the law reform effort to recognize Muslim marriages and Muslim personal law more broadly in South Africa allows us to locate these dilemmas within the

62. Ibid. See Judith E. Tucker, Women, Family, and Gender in Islamic Law (Cambridge and New York: Cambridge University Press, 2008).

63. See Janet Halley and Kerry Rittich, “Critical Directions in Comparative Family Law: Genealogies and Contemporary Studies if Family Law Exceptionalism,” American Journal of Comparative Law 58 (2010): 753-776.

64. See Mary Anne Case, “The Peculiar Stake U.S. Protestants Have in the Question of State Recognition of Same-Sex Marriages,” in After Secular Law, eds Winnifred Fallers Sullivan, Robert A. Yelle, and Mateo Taussig-Rubbo (Stanford, CA: Stanford University Press, 2011), 302. Case notes in the U.S. context that there "is simply very little air between marriage as the state defines it and marriage as Protestants can define it to their flock.”

65. See Halley, “What is Family Law?”. Carole Pateman argues that "the social contract presupposed the sexual contract, and that civil freedom presupposed patriarchal right.” The Sexual Contract (Cambridge: Blackwell, 1988), x. 66. Halley observes that "form-pluralistic systems have an ascriptive character .... [and] are less emphatic about choice, more regulatory, more governmental in the Foucaultian sense than a real menu of options.” Ibid., 32. 
problematic space of modern secular power and the various anxieties and contingencies this gives rise to regarding the limits of liberal neutrality and liberal rights. In this respect South Africa's response to the claims of its Muslim communities sheds light on the two main dilemmas haunting modern liberal accounts of the right to religious freedom. The first concerns the neutrality of the public sphere and the insistence that religion is properly a matter for private life, where religious faith, identity, and ritual are to be simultaneously contained and protected and excluded from public life where rational secular discourse is similarly to be construed and secured. The second concerns the universality of the right to religious freedom and its justification in liberal political morality in terms of competing accounts of autonomy.

The South African case has been shown to complicate these narratives. It allows us to see that the neutrality of the political order is always an abstract particularism comprising contingent settlements and negotiated religion-state establishments. It further allows us to see how the existing contours of the public sphere reflect the "private faith" of communities which have historically embodied the Christian and European traditions of South Africa's colonial past. If correct, the challenge is not further to exclude the claims of religious communities, but to ensure that the public sphere reflects and recognizes the diversity of South Africa's actually existing religious communities.

The South African case also allows us to see that the universality of the right to religious freedom is always a concrete universal claiming normative authority. A value pluralist, groupdifferentiated account of freedom of religion or belief requires the state to recognize a limited sphere of collective autonomy or nomian separation-a space for "associational self-realization in nomian terms." Such a Coverian view of normative and legal pluralism challenges the state's domination of autonomous communities under a unitary law and seeks for the polynomia of legal meaning to be extended to the domain of social practice and control. Thus rather than circumscribing the nomos in a single, statist "Spartan eunomia," it invites in new worlds in the 
form of a complex nomos of "equally dignified communal bases of legal meaning that constitute the array of commitments, realities, and visions extant at any given time.” ${ }^{\natural 7}$ The old adage of "one law for all and no exceptions" on this view gives way to "plural laws for different communities with certain exceptions.”

67. Robert Cover, “Nomos and Narrative,” 57. 